\title{
Fighting oil spills at sea and toxicology of complex mixtures
}

\author{
Hermann M. Bolt
}

Received: 14 January 2014 / Accepted: 15 January 2014 / Published online: 28 January 2014

(C) Springer-Verlag Berlin Heidelberg 2014

A series of spectacular oil spill accidents in the 1970/1980 s, including the disasters of Amoco Cadiz at the Breton shoreline of France (March 16, 1978) and of Exxon Valdez. (March 24, 1989) at Prince William Sound, Alaska, had triggered legislative and regulatory action, both in the USA and in Europe (Schmidt Etkin and Welch 1997; CEDRE 2011; CNN 2013; US EPA 2014). As a consequence, this series of environmental accidents was seemingly discontinued.

Over 20 years later, on April 20, 2010, the explosion occurred on board of the Deepwater Horizon oil rig in the Gulf of Mexico, which until July 2010 released about 240 million US gallons $\left(\sim 9 \times 10^{8} 1\right)$ of crude oil into the North-Central Gulf of Mexico (Allen et al. 2012; CNN 2013). This has been addressed as the largest environmental disaster in US history and the second largest oil spill ever (after the Gulf War oil spill in January 1991; CNN 2013). Multiple pelagic, tidal, and estuarine organisms were affected at the Gulf of Mexico. The immediate toxic ological/ecotoxicological focus was on petroleum ingredients, including polycyclic aromatic hydrocarbons (Barron 2012).

In fighting the Deepwater Horizon oil spill, about 7 million liters of chemical dispersants were used, and for the first time, oil dispersants were used in deep-sea environments (Barron 2012). The main dispersant was Corexit $9500 \mathrm{~A}$ that, according to press releases, contained light petroleum distillates, propylene glycol, and dioctyl sodium sulfosuccinate as detergent (Schor 2010). After preliminary toxicity testing, Corexit was categorized by the US

H. M. Bolt $(\square)$

Leibniz Centre for Working Environment and Human Factors

(IfADo), TU Dortmund, Ardeystr. 67, 44139 Dortmund,

Germany

e-mail: bolt@ifado.de
EPA as "moderately toxic" for two aquatic test species, the Gulf mysid Americamysis bahia and the inland silverside Menidia beryllina (US EPA 2010).

In this journal, Zhang et al. (2013) have reported that the dispersant Corexit 9500A potentiated adverse effects of crude oil on the reproduction of the nematode Caenorhabditis elegans. Yet, the mode of action of such toxicity remained unknown. It was underlined that combination effects of chemical dispersant(s) with crude oil ingredients should be taken into account in possible future maritime cleanup applications.

In this issue of Archives of Toxicology, the same group reports on its further investigations into the underlying mechanisms (Polli et al. 2014): The crude oil-dispersant mixture increased the number of apoptotic germ cells in treated $C$. elegans and led to changes in expression of a number of genes at the same time. These gene expression changes led to the conclusion that the germ cell apoptosis induced by the chemical mixture was CEP-1 dependent. Also, the anti-apoptotic ced-9/Bcl-2 was activated in response to the increase in cell death.

With this first insight into the mode of action, the publication provides an invaluable methodological hint for further studies into the complexity of interactions, which finally leads to potentiation of this type of toxicity. The case is of highest practical relevance, within a field that is not sufficiently investigated.

\section{References}

Allen SE, Smith BW, Anderson KA (2012) Impact of the Deepwater Horizon oil spill on bioavailable polycyclic aromatic hydrocarbons in Gulf of Mexico coastal waters. Environ Sci Technol 46(4):2033-2039 
Barron MG (2012) Ecological impacts of Deepwater Horizon oil spill: implications for immunotoxicity. Toxicol Pathol 40:315-320

CEDRE [Centre of Documentation, Research and Experimentation on Accidental Water Pollution] (2011) Amoco Cadiz. Last updated April 26, 2011. http://www.cedre.fr/spill/amoco.php. Accessed 5 Jan 2014

CNN (2013) Oil spills fast facts. CNN Library. Last updated Oct 5, 2013. http://edition.cnn.com/2013/07/13/world/oil-spills-fast-facts/. Accessed 5 Jan 2014

Polli JR, Zhang Y, Pan X (2014) Dispersed crude oil amplifies germ cell apoptosis in Caenorhabditis elegans, followed a CEP-1 dependent pathway. Arch Toxicol [this issue]

Schmidt Etkin D, Welch J (1997) Oil spill intelligence report international oil spill database: trends in oil spill volumes and frequency. 1997 International Oil Spill Conference, (pp 949-952). http:// large.stanford.edu/courses/2011/ph240/mina1/docs/01480.pdf. Accessed 5 Jan 2014
Schor E (2010) Ingredients of controversial dispersants used on Gulf spill are secrets no more. The New York Times, June 9, 2010. http://www.nytimes.com/gwire/2010/06/09/09greenwire-ingredien ts-of-controversial-dispersants-used-42891.html. Accessed 5 Jan 2014

US EPA (2010) Comparative toxicity of Lousiana sweet crude oil (LSC) and chemically dispersed LSC to two Gulf of Mexico aquatic test species. US Environmental Protection Agency, Office of Research and Development. http://www.epa.gov/bpspill/reports/ updated-phase2dispersant-toxtest.pdf. Accessed 5 Jan 2014

US EPA (2014) Exxon Valdez. Last updated Jan 2, 2014. http://www. epa.gov/oem/content/learning/exxon.htm. Accessed 5 Jan 2014

Zhang Y, Chen D, Ennis AC, Polli JR, Xiao P, Zhang B, Stellwag EJ, Overton A, Pan X (2013) Chemical dispersant potentiates crude oil impacts on growth, reproduction, and gene expression in Caenorhabditis elegans. Arch Toxicol 87:371-382 